Historic, Archive Document

Do not assume content reflects current scientific knowledge, policies, or practices. 


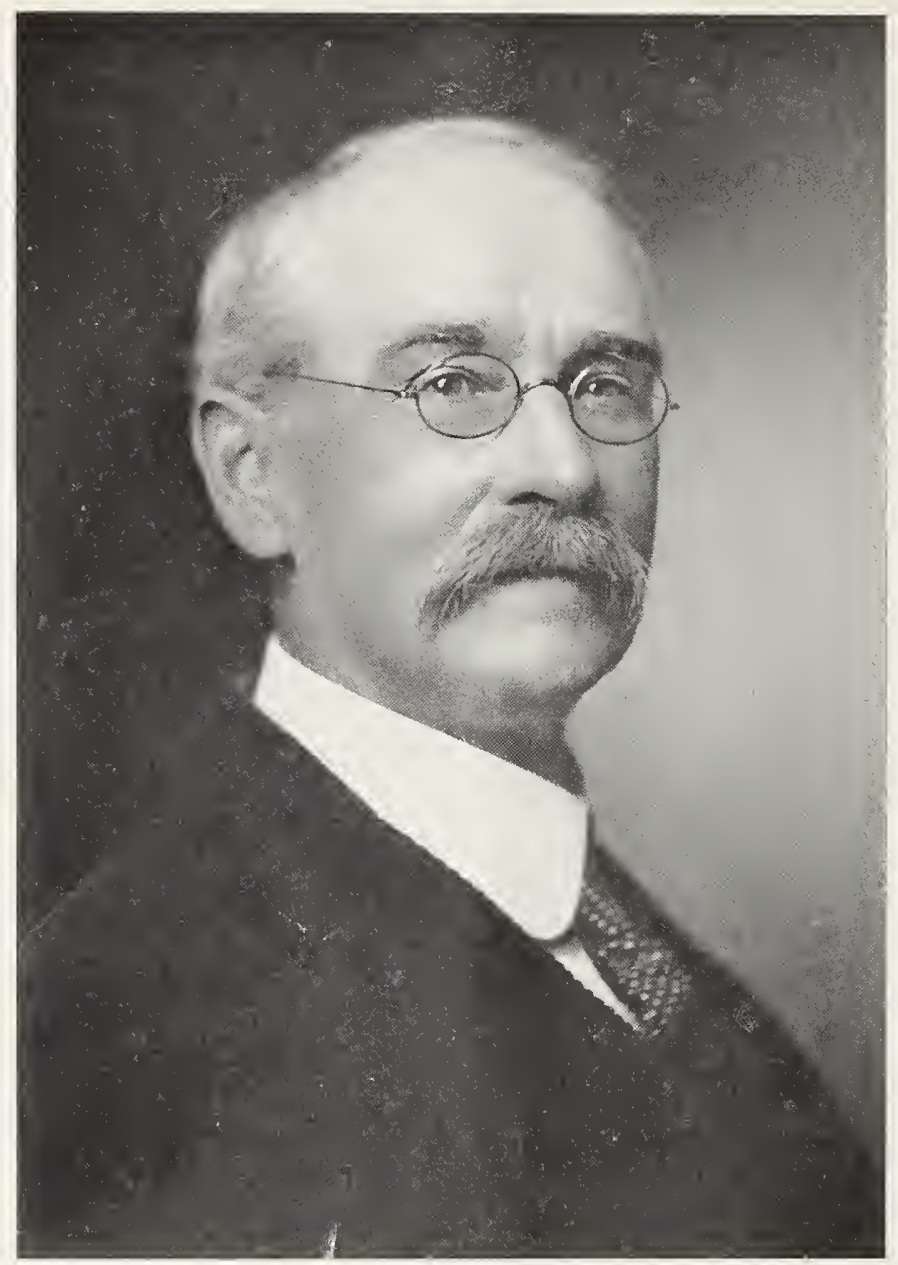

G. M. BACON

Founder and President of The G. M. Bacon Pecan Co.

A Pecan enthusiast for many years. He planted his first trees in 1885

The Scenes in This Book Are Photographs Taken

On Our Property at De Witt, Ga. 


\section{THE PECAN}

ПHE CATAlog OF THE G. M. BACON

1 PECAN COMPANY, A CORPORATION

LOCATED AT DE WITT, MITCHELL COUNTY,

IN THE STATE OF GEORGIA. ITS DULY

ELECTED OFFICERS ARE: G. M. BACON,

PRESIDENT; R. J. BACON, FIRST VICE PRESIDENT; W. B. GILLICAN, SECOND VICE PRESIDENT; DE WITT C. BACON, SEC.-TREAS. 


\section{FOREWORD}

$\mathrm{N}$ O one thing in agriculture, horticulture or aboriculture has ever made such wonderful growth, as has the Pecan industry in the last decade. The history of the world records nothing that will even approach its marvelous delvelopment.

Previous to this, Pecans were generally regarded as a good thing, but the uncertainties attending seedling trees, put a decided limit to operations. Although some interest had been manifested, plantings were limited to a comparatively few small groves.

After many years of work and experiment, the science of budding and grafting Pecans was perfected at the beginning of the present century. This made the planting of Pecan orchards commercially feasible, as desirable trees could be had at reasonable prices, with ultimate results certain. Interest was aroused, and soon became general. Great enthusiasm prevailed, and resulted in the planting of many groves, large and small.

The sensational and rapid advances in the value of lands after planting to Pecans, can be compared only to the wonderful strides of the industry itself. For the same expenditures, there is probably nothing that has ever equalled it. Lands that were a hard sale at ten dollars an acre, brought ten to twenty times as much, a short time after planting. Owners of bearing orchards have refused $\$ 1,000$ per acre for their holdings, saying there was nothing they could re-invest the money in, that would bring them the income their Pecan trees do. And there will be many years of constantly increasing returns, before the maximum yields are finally reached.

As this Company was one of the pioneers in the Pecan business, it naturally follows that it should own one of the very oldest budded and grafted Pecan orchards in the world. This orchard covers approximately 600 acres, and contains nearly 11,000 trees. The trees are from eight to twelve years old, and are all bearing. It also owns a seedling orchard of several hundred trees, about thirty years old.

The nurseries contain some sixty thousand budded and grafted trees, ready for delivery, and in addition, there are thousands of stocks for future workings.

We have been growing and selling Pecan trees and pecan nuts for nearly thirty years. We have shipped to all parts of the Union, and to many foreign countries as well. We have made thousands of friends, and our pleased and satisfied customers are legion. 


\section{HOW PECANS ARE PROPAGATED}

7 HE natural way for any form of plant life to reproduce its kind, is through its seed. Seed are produced from the blossoms, which are sexual. That is, part of the blossoms are staminate, or male, and the others are pistulate, or female. The pollen from the stamen is carried by the wind, insects or other agencies to the pistil, which it fertilizes, and a seed begins to grow. If no pollen reaches the pistil, no seed is formed.

When the seed matures, it drops to the ground, and if favored by chance, sprouts and proceeds to make another tree. Trees grown direct from the seed, are called Seedlings.

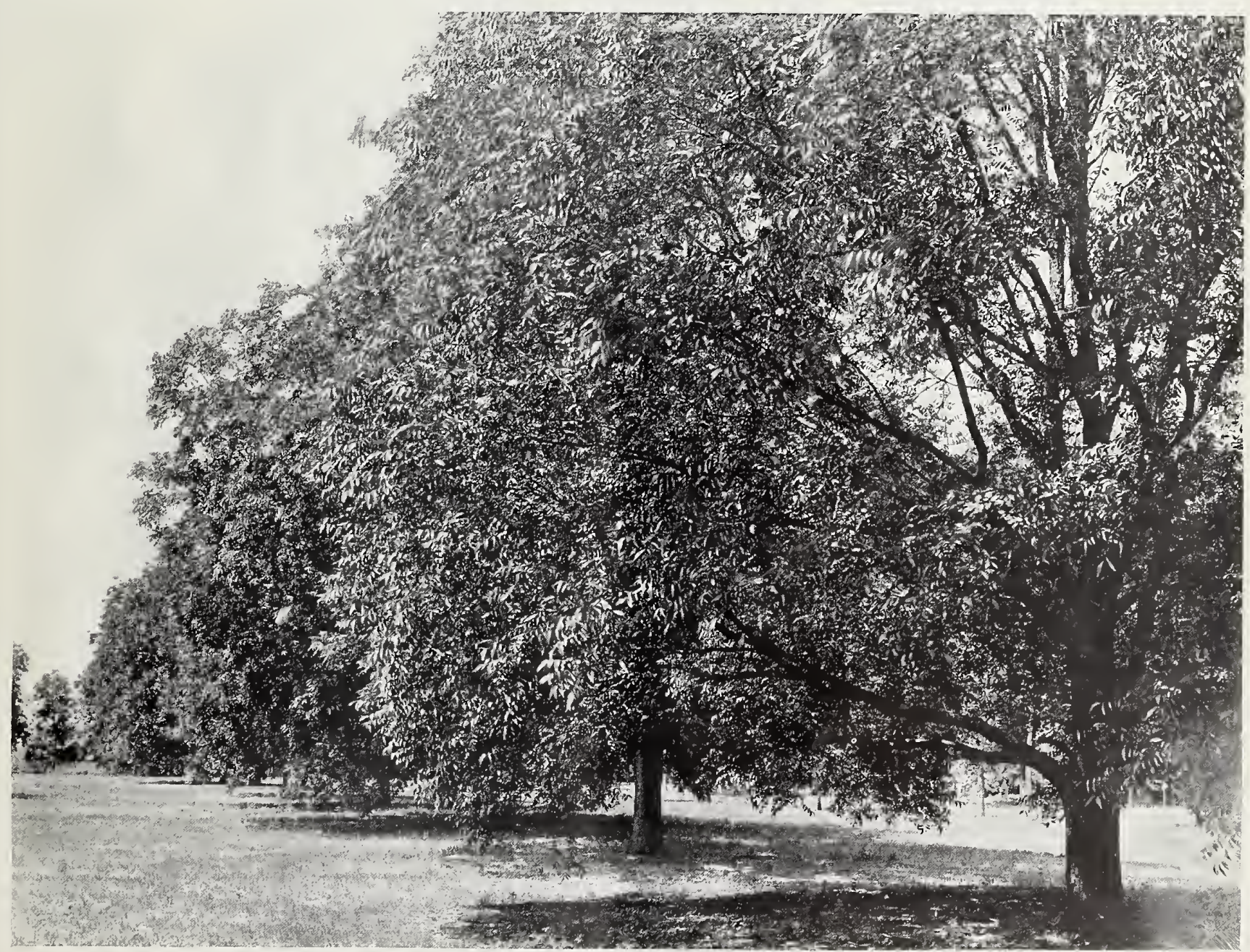

A ROW OF GRAND OLD PECAN TREES

For reasons more or less understood, many kinds of seed do not reproduce trees exactly like those that bore them. Pecan seed seldom, if ever do, and the difference is often very marked. Consequently, if there were no other way of reproducing trees except by planting seed and growing seedlings, orchards containing thousands of trees alike in all their many and various characteristics, and all bearing fruit exactly alike, would be impossible. 
Fortunately, there are ways by which this can be overcome. Perhaps the best understood method of propagation, other than by growing direct from the seed, is by cuttings. By this method, a twig is cut from a tree, shrub, or vine, and one end planted in the soil. This end takes root, and it grows to be a tree, shrub or vine, as the case may be. But, unlike a seedling, in each and every way, and in each and every characteristic, it will be exactly like the tree, shrub, or vine, from which it was cut. It cannot by any possibility deviate in any way, any more than it could if left to grow as a branch on the parent.

But cuttings from some kinds of trees, are very difficult to make root. Others can be rooted easily. but the trees so grown may have very faulty root systems, or for various other purely mechanical reasons, do not make desirable trees.

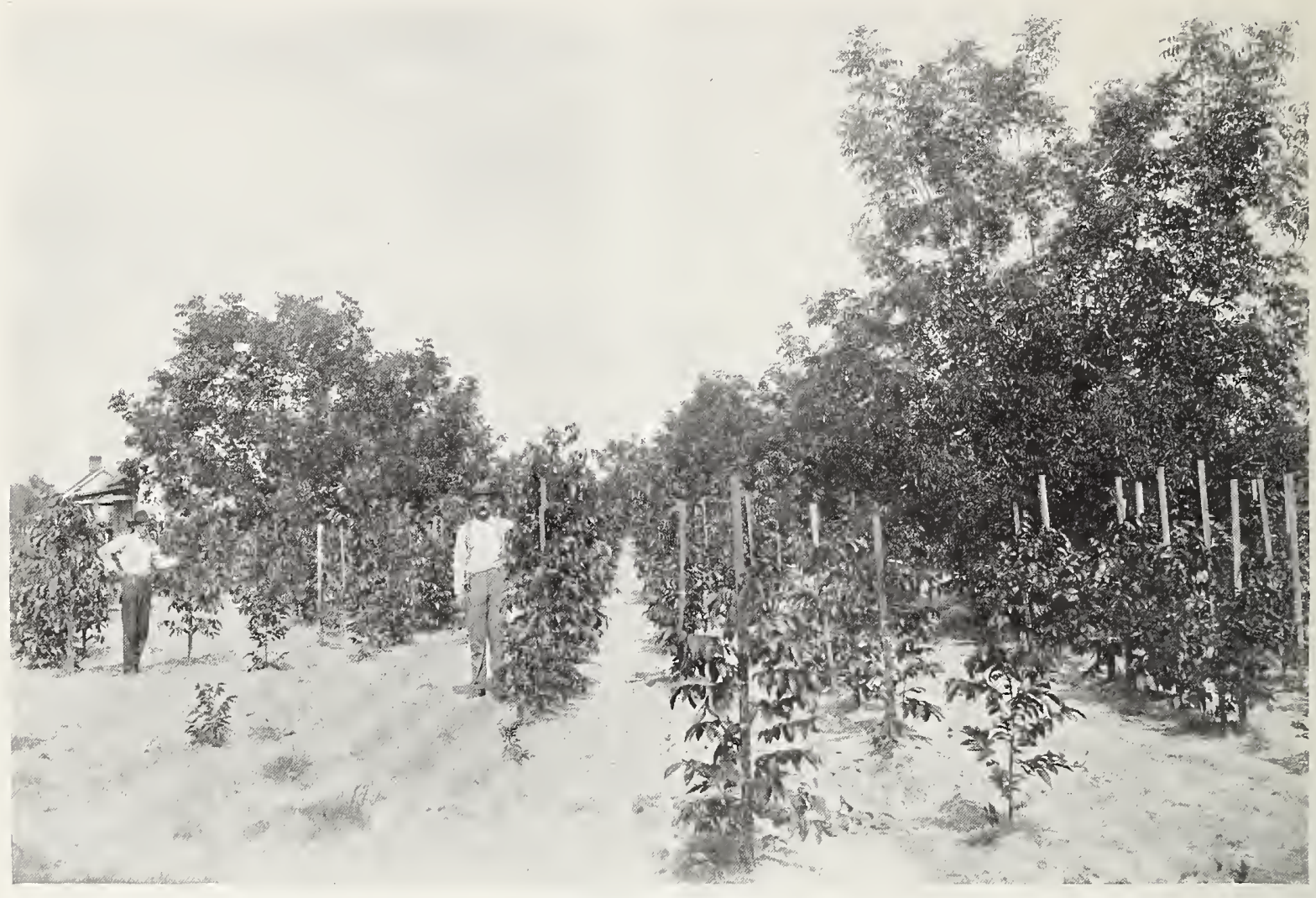

SCENE IN NURSERY

When little trees incline to lean to one side, or grow crooked, they are carefully tied to stakes, to train them up straight and truz

This difficulty in turn, is overcome also. Instead of planting the cutting, and depending on it to grow its own roots, the cutting is joined, or grafted, to a seedling. Thus the seedling furnishes the roots, and the cutting the top. This makes it possible to have orchards of unlimited size, with each and every tree exactly like the parent tree in each and every characteristic, and each exactly like all the rest.

It must be remembered that nothing resembling a cross can take place as a result of grafting. The cutting retains every characteristic, as certain and true as though growing on roots of its own make. The only way to effect a cross in vegetation, is through the pollenation of the blossoms. 
Seedlings that are grown for the purpose of making root systems are called stocks and the cuttings that are to be joined to them, are called cions. The process of joining them together, or making the union, is called grafting. The result is known as a grafted tree.

The principle of budding, is the same as grafting, but the process is different. While grafting must be done in the winter, budding must be done in the summer, when the bark will slip. By this method, a bit of green bark, containing a bud, is taken from the tree to be reproduced, and transferred to the stock. If properly done, and carefully tied and waxed, the bud will soon develop a twig, and the twig grow into the desired tree.

All the skill, knowledge or experience required in budding or grafting, is in the making of a successful union. If this is accomplished, future results are the same No one nurseryman can turn out any better trees than another, insofar as his methods of budding and grafting are concerned. If the union is made, and the bud or cion lives and grows, it is a complete success. If the bud or cion dies, it is a complete failure. There is no middle ground.

In our own work, we use exclusively buds and cions taken from our own bearing trees. The many advantages this gives us, are evident, being certain as to what we are using. It also reduces to the minimum, the chances of making mistakes, and the mis-naming of varieties.

\section{SEED FOR PECAN TREE STOCKS}

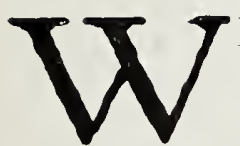

HILE it is true that none of the characteristics of the stocks is transmitted to the budded or grafted top, it can readily be seen that the roots must be capable of fully sustaining the trees they are to hold up and feed. A poor root system must of necessity mean a poor tree.

While the physical processes of budding and grafting Pecans have been practically perfected, final results in some phases are as yet unknown. But the budding and grafting of other trees has been going on for many generations, and the lessons learned and experiences gained in other branches of horticulture, should be given serious consideration.

Seeds taken from fruits grown on budded or grafted trees, are seldom planted to make stocks for apples, peaches, pears, etc. Experience has demonstrated that such seed do not generally make satisfactory stocks. Nurserymen propagating these fruits, prefer seed from seedling trees. Citrus nurserymen have found that the best seed they can use for stocks for oranges, lemons grapefruit, etc., is from the wild seedling sour orange.

Whether or not Pecan stocks grown from nuts from budded and grafted trees will prove deficient, we do not know. Eventually, time will demonstrate this. But to be on the safe side, we use seedling nuts in our plantings. So far, every indication demonstrates that the trees in our orchards are on roots that not only have, but will continue always, to fulfill every requisite desired of them. The trees in our nurseries are, of course, on the same kind of roots.

We have been fortunate, from the very beginning, in always having on hand, from our own groves, an abundance of healthy seedling nuts to plant for stocks. We have never had to buy nuts, with no knowledge of the health vigor or other conditions of the trees that bore them.

Our splendid orchards of strong, robust seedling trees, have yielded many more nuts than we ever needed for seed. When we plant these nuts, we can depend on practically every one germinating, and quickly producing a little tree, full of kick and ginger, that grows off with a jump.

It is a source of great satisfaction to us, to know that the budded and grafted trees in our orchards, and those in our nurseries which we will supply to our customers have roots of this kind under them. 


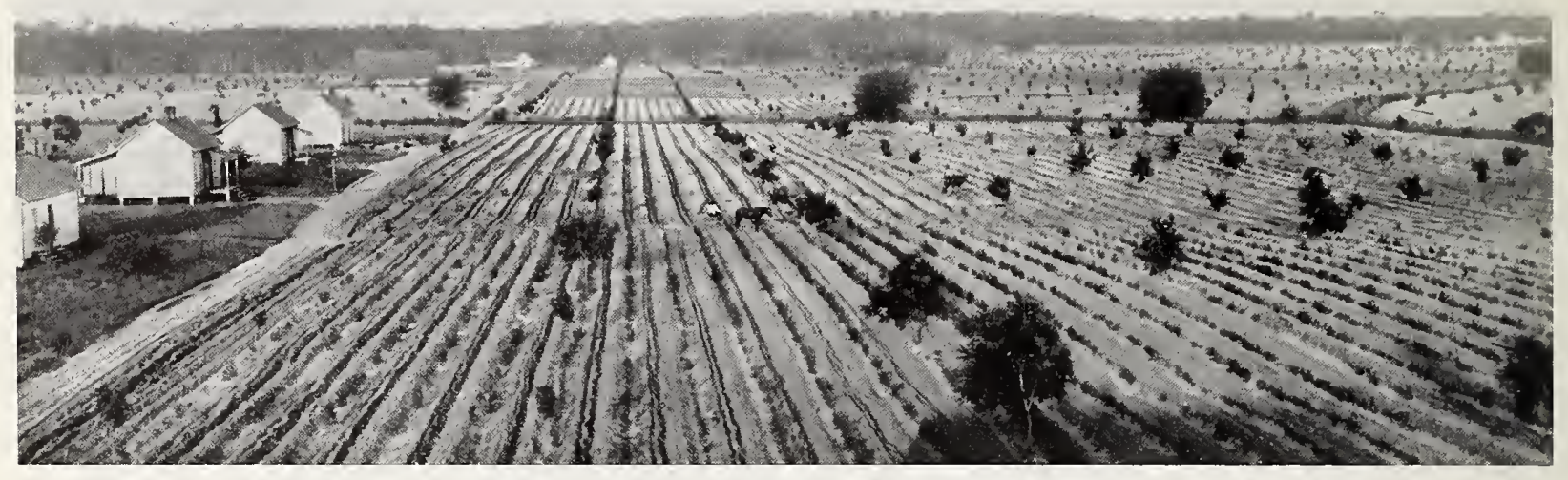

YOUNG PECAN ORCHARD, PHOTOGRAPHED IN 1908

Nursery stock growing between the tree-rows. Large trees in center were oaks, which have been removed

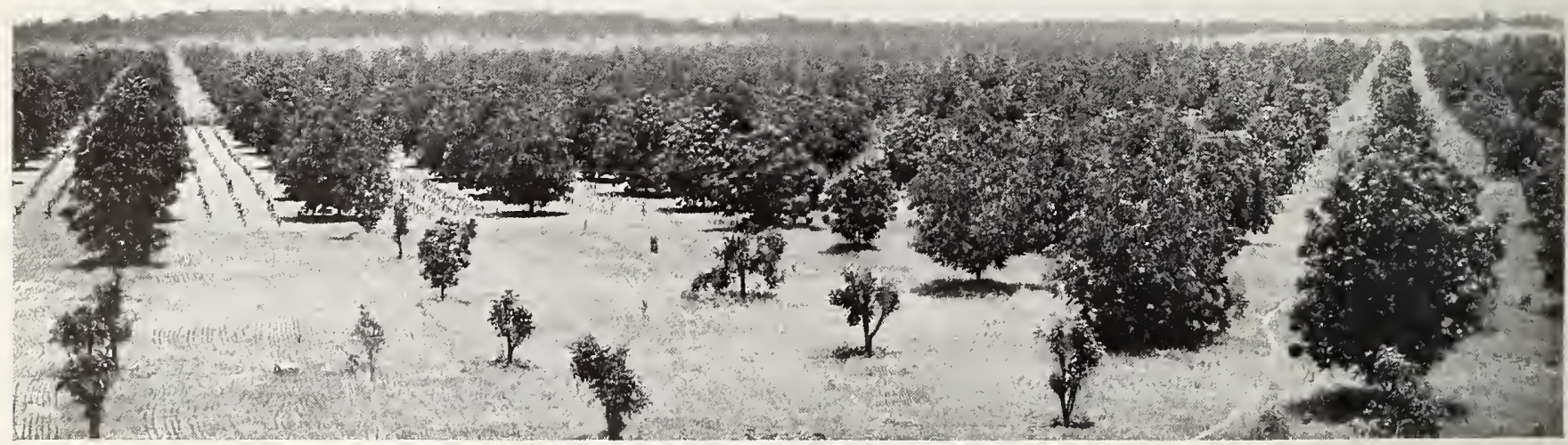

SAME ORCHARD PHOTOGRAPHED IN 1915

Showing the wonderful growth accomplished in seven years. This orchard is now netling splendid returns 


\section{LANDS SUITABLE FOR PLANTING PECANS}

A

S Pecan groves are in successful operation in practically all of the Southern states, and in various sections of each of these states, it follows that the Pecan will flourish in any tillable soil. Of course, the more fertile the soil the better, but even on very poor lands, it will do well.

It can be safely said, that any land that will grow cotton, corn etc., is well suited for Pecans. In addition, lands along creeks and rivers subject to overflow, ean be used with splendid results. The great majority of the wild Pecan groves of Louisiana and Texas, are in such swamps.

One of the best places to plant Pecans, is around the home, the barn, ete. Many of the finest and heaviest bearing trees, are those close to the habitations of men and his domestic animals. This, in fact, seems to be the ideal place, and certainly there is no more ideal tree for lawns and yards than the Pecan. In summer, its dense shade is ever welcome. In autumn, when its leaves fall, they dry out and break up very quickly, and unlike the unsightly and lasting litter made by the leaves of many shade trees, soon disappear. In winter, the absolutely bare limbs offer no resistance to the warm, purifying, and welcome rays of the sun. And last, but not least, the annual crop of nuts not only supplies the family with a delicious and healthful food, but furnishes a substantial increase to the income of the fortunate owner of the trees.

\section{MARKETS AND MARKETING}

I

S THERE DANGER in over-production? This is the question often asked by those who contemplate planting Pecans, and seems to cause many to hesitate. Overproduction may be possible, but from the present outlook, it is highly improbable.

There are today, many thousands of people all over the North and West, able to pay high prices for Pecans and would no doubt be willing to, but they have actually never heard of them. This enormous field will be opened as fast as the supply comes in sight to meet the demand.

The latest census reports (1909) show that the production of nuts of all kinds that year in the United States was valued at $\$ 4,500,000$. For the same year imports of foreign-grown nuts amounted to $\$ 15,000,000$, nearly four times as much as the domestic output. The imports were largely English Walnuts, Almonds, Brazil Nuts, Filberts and Hazel Nuts. Most of these nuts are inferior to the ordinary Pecan, and none can compare to the Paper Shell varieties.

Many thousands of pounds of English Walnuts and Peanuts are used by confectioners in the manufacture of candies. Very few Pecans are used by them, for the simple reason the supply is very limited. And Pecans are very popular with confectioners.

So, it can be scen that there is plenty of room to market millions of dollars worth of Pecans right here in this country. And long before the American markets are glutted, Europe will be at peace. Then there is South America, Australia, Africa and Asia, and there are many thousands of people on these continents, who are able and will be willing to buy, once they know what Pecans are. 
The invested capital of this Company in nurseries, is very much smaller than that in orchards. If there was the slightest possibility of glutting the nut market, we would not be trying to influence others to plant trees. But the fact is that the more orchards that come into bearing, the easier it will be to sell the nuts. Already there are several companies organized for the purpose of introducing and selling Pecans. The more bearing Pecall orchards there are, the more of these companies there will be, making it much easier for the growers to sell, and at far better prices. Don't let the bug-a-boo of over-production influence you.

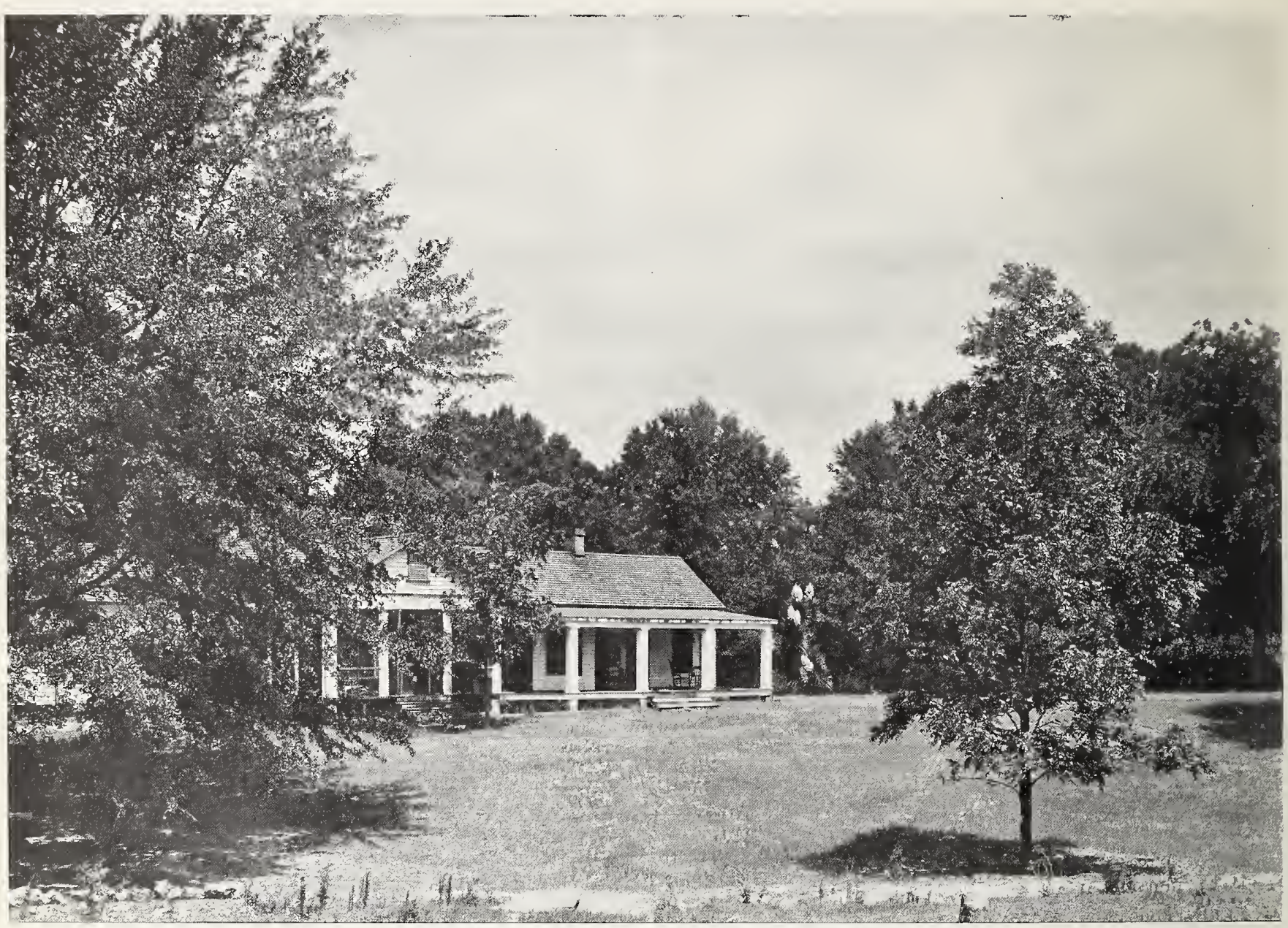

RESIDENCE OF MR. G. M. BACON, AT DE WITT, GA.

\section{NO SECRETS}

W E have no desire to say anything disparaging in regard to other nurserymen, but just a word in our own defense.

There are no secrets or "private methods" in the growing of Pecan trees. Every process, from the preparation of the soil and the planting of the nuts, to the final packing and shipping of the trees, is known to all competent nurserymen alike. 
Knowledge and experience are, of course, very essential in the production of vigorous, healthy, desirable trees. Careful attention and plenty of hard work must necessarily follow, just as it does to make a good crop of any kind.

The proper packing for safe shipment is also of the greatest importance. Carelessness or ignorance here, has often been the cause of heavy loss and keen disappointments, and has made dismal failures of what might otherwise have been successful and valuable groves.

But those who claim in their advertising, to have discovered some new and wonderful process of budding or grafting, or other exclusive stunts which gives their products some vast superiority, are only talking

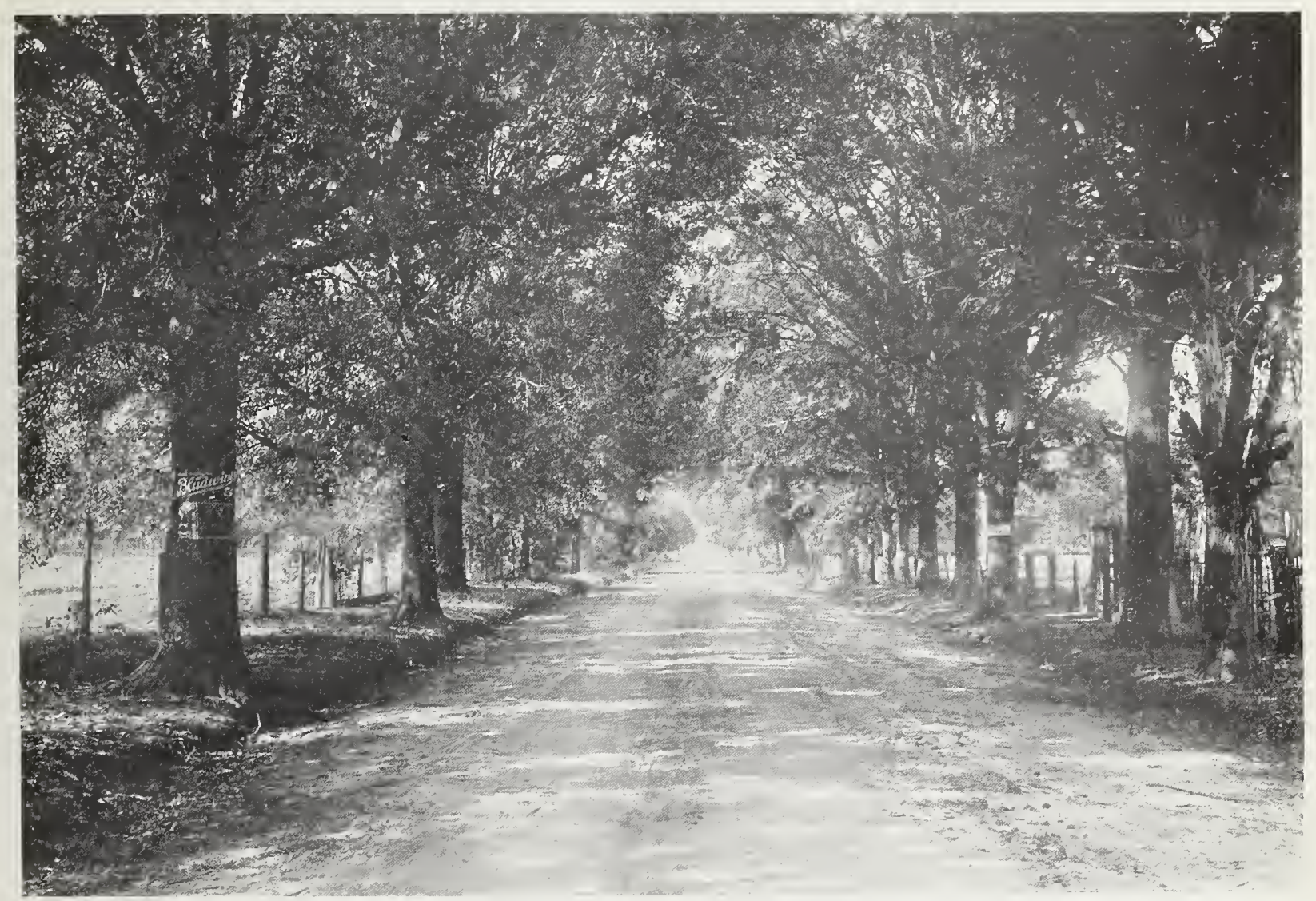

WHERE THE DIXIE HIGHWAY PASSES THROUGH OUR CRCHARDS

\section{VARIETIES OF PECANS}

UST how many seedling Pecan trees there are in the world, is hard even to estimate. It is safe to say, however, that they run into the millions.

Each one of these trees is a separate variety. That is to say, there are no two seedling trees to be found in the world, that are exactly alike in all characteristies. 
All varieties of Pecans of necessity originated as seedlings. Once in a great while, by the merest chance, a seedling tree will develop many desirable characteristics, such as early and prolific bearing, large well-filled nuts, thin shells, ability to resist disease, etc.

Out of all the millions of seedling trees, hardly more than a dozen have developed these characteristics to a sufficient extent to make them worthy of continued propagation. As it takes from twelve to twenty years, or perhaps longer, to test a new variety out thoroughly, it is easy to see the danger in planting untried kinds.

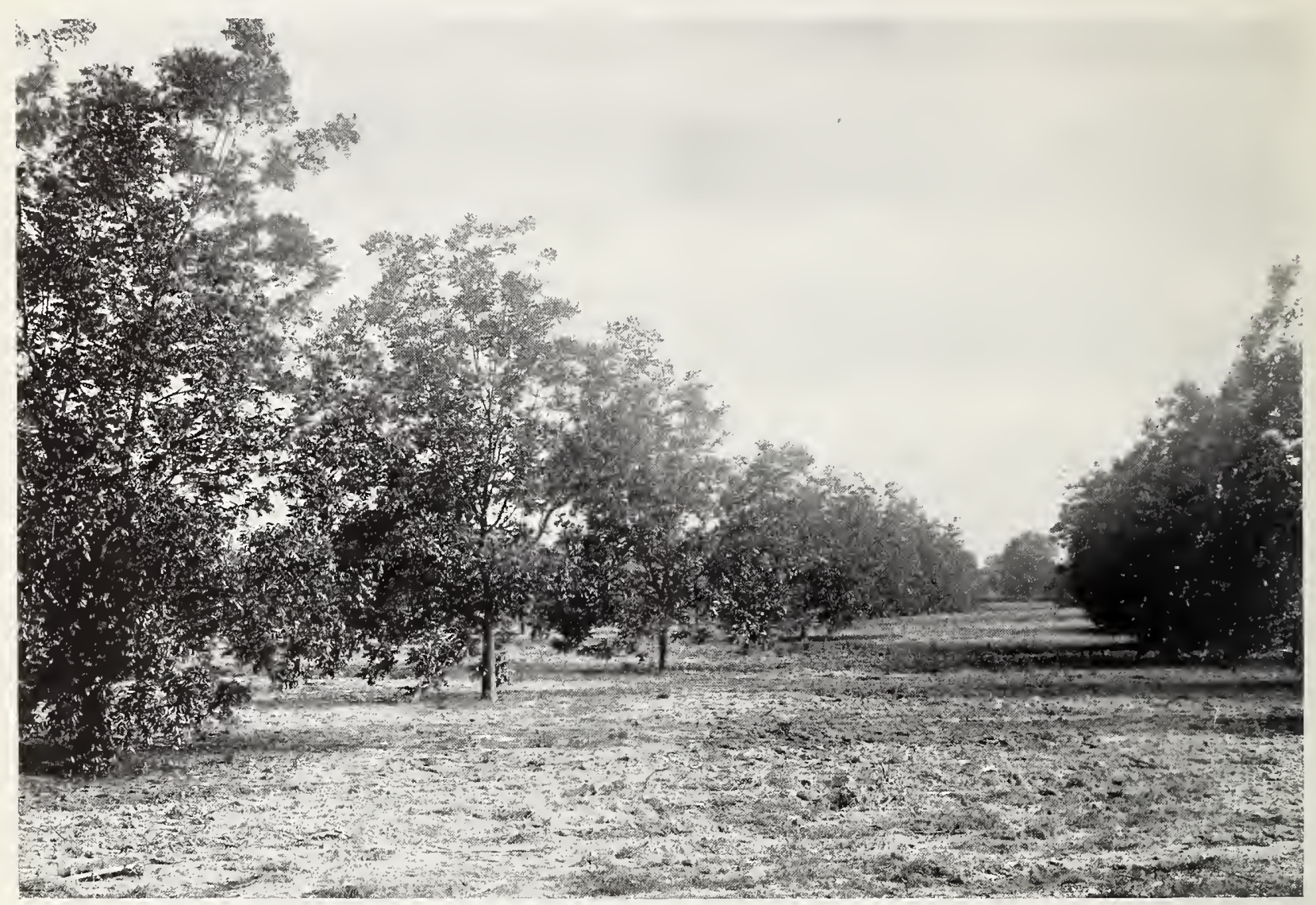

VIEW IN ONE OF OUR ORCHARDS

The varieties we offer are considered the best to be had. We have tried out a number of other varieties in our orchards, and observed many more, but our long experience with commercial orchards has reduced the number we propagate and offer to our customers, those described.

These varieties are standard. They have not only been thoroughly tried out by us, but by many other orchardists as well. None of them are perfect, but all of them can be grown at excellent profits.

If offered other varieties, investigate them well before tying up your money, iands and time. That there are other varieties as good, and some no doubt better, than those we offer, is more than probable. But to know with certainty that they are, is the problem.

We advise planting at least three varieties in each orchard. This is recommended principally on account of the much better pollen distribution, which is very necessary to full yields. 


\section{THE FOLLOWING VARIETIES ARE OFFERED AND RECOMMENDED}

Stuart One of the first varieties introduced, and is still very popular. Very prolific bearer of very large nuts, of good flavor and quality.

Schley Medium to large nuts, of rich, sweet and delicate flavor. Shell very thin, and easy to crack. Considered by many to be the best of all Pecans. Not as prolific a bearer as some of the other varieties, but gives good yields. Be sure to include some Schley's in your order.

Van Deman The parent tree is now nearly eighty years old, and is thrifty and healthy, and bearing large crops. It is a strong and vigorous grower. Nuts extra large, and of good flavor and quality.

Frotscher A strong, handsome grower. One of the very largest nuts and very thin shell. Excellent flavor.

Russell Medium to large nuts, of good flavor and quality. Thin shell, and cracks easily. A good all-round variety.

Alley A budded tree of this variety produced thirty pounds of nuts in its sixth year from setting out. It is a profuse bloomer and very heavy bearer. A favorite with many orchardists.

Pabst Large size nut of very attractive appearance. Flavor and quality good. Early bearer and productive. It is becoming very popular.

Delmas Another very attractive nut, and bears very early. The tree is a particularly handsome grower. Owners of bearing trees of this variety, report splendid results.

Money Maker A very handsome tree, with pale green foliage. Very vigorous ing very popular.

Teche Although not as large a nut as most of the other varieties, many orchardists claim that it is most profitable, on account of its prolific bearing tendencies This and other advantages, make it a prime favorite with many. 


\section{IN CONCLUSION}

$\mathrm{F}$ OR many years the efforts of Southern economists have been directed towards weaning the farmers away from "all cotton." Most farmers accept the gist of their arguments, and are endeavoring to "diversify." Stock and poultry raising are now commanding very serious attention in all sections.

But a great drawback to stock raising on many Southern farms, is lack of shade. And abundant shade is absolutely necessary for stock of all kinds, during our long, hot summers.

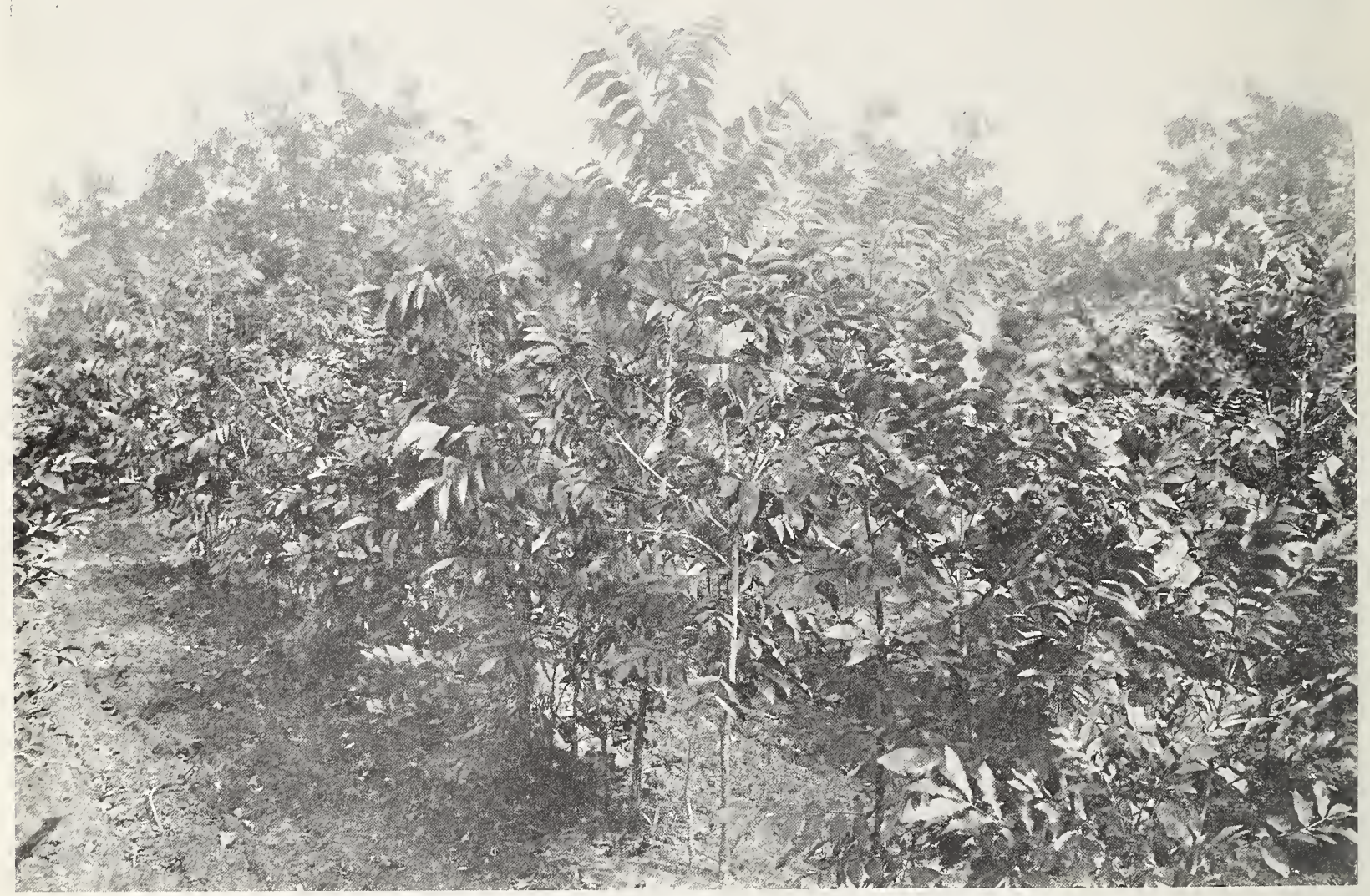

A CLOSE-UP NURSERY VIEW, SHOWING STRONG UPRIGHT GROWTH OF TREES

Pecans present a wonderful opportunity to stock and poultry raisers. Here is a splendid quick growing tree, making a good shade during the entire hot weather. And then, when the shade is no longer needed, the real worth of the trees come in, with the harvesting of a valuable crop. Stocks and grain will keep our money in the South, while nuts and cotton will bring it in from all the world. The Pecan is primarily a money crop, but unlike cotton, it is a valuable adjunct to any farm, in many other and profitable ways. Plant Pecans and let them help you diversify. 


\section{TESTIMONIALS}

\section{A FEW LETTERS OF INTEREST, TO SHOW THE TREND OF MANY MORE}

From N. A. KIRVEN, Chat tanooga, Tenn.

\author{
June 15, 1915.
}

"I am so well pleased with the two extra large trees you sent me last, and having had so far such grand success with them I am inclined to place an order for four or six (the samesize) for next season's delivery. As I have always said you cannot get something for nothing. I do not consider the price when it comes to buying nursery stock, as I always want the best and finest to be had, especially when it comes to Pecan trees, as I want them for beauty, shade, and early bearing."

From F. L. THOMAS, Glio, Alabama.

August 24, 1915.

"Trees I bought of you last season are doing fine. Patrons were well pleased with them."

From J. E. HECHT, Monticello, Ga.

June 23, 1915

"The trees bought of you last December are all growing and in first class shape. Your records will show that I bought trees from you in 1910 and also in 1911, so now I have something like 200 trees, and by actual count 53 of these trees had bloons on them this year and a few of them had Pecans on them within two years after you shipped them to me. I have had less than $5 \%$ of the trees die that I bought of you and now my orchard of 200 trees will, if they continue to grow as they have for the past two years, be a grove of valuable trees."

From W. P. LAW, Darlington, S. C.

Jume 26, 1915.

"These trees are all doing nicely. I was particular in giving them a good start when I set them out and they have taken on growth very rapidly. It may interest you to know that my father has 2,700 trees which were planted FROM THE NUT in 1900 . These trees are just beginning to bear."
From J. MORTIMER, Jr., Lumber, S. C.

$$
\text { Junข 21, } 1915 .
$$

"Every tree purchased from you was put out and every one is living, thriving, and growing splendilly. I see no reason why I should lose at this late date a single tree. I am much pleased with results obtained and frank to say I think all should be attributed to the nice salection you made and your proper an 1 careful packing for shipment."

From J. S. MILLERMAN, Corsicana, Texas. June 19, 1915.

"The trees which I bought from you last February are every one living and seem to be growing fine. I am well pleased with them."

From J. M. DARDEN, Suffolk, Va.

May 21, 1915.

"Every tree bought from you is living and doing fine. I expect to send you some of the prettiest Peaans grown from these trees (Xmas, 1919) and I will prove to you what we can grow in this grand old stats. I am going to try to interest some of the farmers around here in Pecans, so when you are ready to ship kindly atvise me. Of course, I make no profit on these trees. I simply want my friends to plant them as an experiment.",

From Mr. JOHN M. BREWTON, Glennville, Ga.

May 26, 1915.

"The trees I got from you are doing fine. Some of them bore 40 or 50 lbs."

From Alex. A. Boone, Toomsboro, Ga.

"Trees bought of you doing very well. I may want anywhere from 5 to 50 the coming season."

\section{HIGHEST AWARDS}

Were conferred upon our exhibits of Pecans at the World's Fair in St. Louis, 1904, and evidenced by a Gold Medal and two Diplomas. And again at Jamestown, 1907, and evidenced by a Silver Medal and Diploma 


\section{PLANT PECANS}

TF YOU CAN'T PLANT A

1 large orchard, Plant

A SMALL ONE. IF YOU CAN'T

PLANT A SMALL ONE, YOU

CAN PLANT A FEW AROUND

THE HOUSE AND LOT; BE-

FORE YOU DO ANYTHING ELSE

PLANT PECANS 